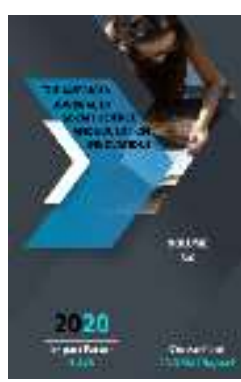

Journal Website: http://usajournalshub.c om/index,php/tajssei

Copyright: Original content from this work may be used under the terms of the creative commons attributes 4.0 licence.

\section{On Models Developed By Scientists In The Field Of Simultaneous Interpretation}

\author{
Adolat Iskandarovna Shasalimova \\ 2nd Course Master Student, Specialty "Simultaneous Interpretation (Chinese)", \\ Department “Translation Studies And International Journalism", Tashkent State University Of \\ Oriental Studies, Uzbekistan
}

Nilufar Bekmuratovna Khodjaeva

PhD, Head Of The Department "Translation Studies And International Journalism", Tashkent State University Of Oriental Studies, Uzbekistan

\title{
ABSTRACT
}

This article describes the models that can be used in the process of simultaneous interpretation and their analysis by scientists who have conducted research in the field of simultaneous translation. Each scientist's model has its own characteristics and features.

\section{KEYWORDS}

Simultaneous translation, model, text, research, coding, decoding, cognitive, processing.

\section{INTRODUCTION}

It is known that the social, political, economic, cultural, spiritual and educational ties between many countries of the world are developing day by day. In particular, the intensification of friendly relations between Uzbekistan and the countries of the East is a pressing issue in the training of high-level simultaneous translators in the field of basic Oriental languages.
Simultaneous interpretation is mainly based on the ability to speak in the auditory process, and a simultaneous interpreter is required to have the original language and the target language, as well as the ability to think in two languages at the same time. As for the term "simultaneous translation", the word "synchronous" is derived from the Greek, "syn" - together, "chronos" - time, that is (synchronos) "simultaneously", "In 
accordance with each other, which happened or will happen at the same time", "belonging to synchronism, synchronicity" as one of the important terms of the industry has been mastered in several languages of the world. Dictionaries also define the term "synchronism" as "the precise coincidence of two or more events or processes occurring at the same time".

Interpreting is a special type of communication between languages and cultures and a highly technical profession [2, p. 91].

同声传译 tóngshēng chuányì Simultaneous interpretation appeared in the 1930 s and is one of the newly formed terms in linguistics, known in English as "simultaneous interpretation", "language interpretation", and in Russian as "synchronous interpretation". In Chinese, the term has “同声翻译”, “同步口译” synonyms.

同声传译 tóngshēng chuányì simultaneous translations consist of 同声 tóngshēng «unanimous" +传译 chuányì "translate" components, abbreviated as 同传 tóngchuán . The term 同声传译 tóngshēng chuányì is defined in the Modern Chinese Glossary as follows: an interpreter translates the content of a speaker's speech to the audience without interrupting it. This method of interpretation is widely used in international conferences, diplomatic affairs, business and other fields. The term 同声传译 tóngshēng chuányì simultaneous interpretation has 同声翻译 tóngshēng fānyì and 同步口译 tóngbù kǒuyì synonyms in Chinese [3].

Simultaneous interpretation is an interpretation in which the interpreter hears the speech message in the original language by ear and performs it in parallel [4, p. 8].

Simultaneous interpretation plays an important role in the international communication scene as a form of interpretation [5].

Simultaneous interpretation is a type of interpretation in which a speaker simultaneously translates his speech along with the speaker's speech [6, p. 98].

Simultaneous interpretation is a complex cognitive activity that performs multiple tasks in parallel [7].

Simultaneous interpretation is a complex cognitive process that requires the translator to listen and speak at the same time, that is, to control the translation, and his or her cognitive burden is higher than that of any other language activity.

Among all types of translation activities, simultaneous interpretation is the most timelimited and offers the least opportunity to select the speed of information processing and reproduction. If a translator working in written translation mode, for example, can take a full working day to translate 6-8 printed pages, a simultaneous translator will have to complete the translation during the time the speaker pronounces the original text. In other words, a simultaneous translator is given 20-30 times less time to translate the same amount of text than a written translator. The time of a translator working in serial translation mode will also be much more limited, but compared to a simultaneous translator; he will have twice as much time to translate a text of the same size: the time the original text is spoken by the speaker and the text the time spoken in the translated language.

The simultaneous interpretation process is characterized by the following features:

- A higher rate of translation of the original text into the text of the target language than other types of translation;

- The speed of translation is strictly dependent on the speed of speech by the speaker in the original language; 
- Decide on translation immediately after referral to each individual department.

Scholars in the field of simultaneous interpretation in Uzbek, Russian, English and Chinese linguistics are doing a lot of work.

Simultaneous interpretation is a very complex cognitive task in which translators have to listen, understand, memorize, produce and monitor at the same time. Since the 1970s, various cognitive models of this complex task have been developed, including the data processing model (Gerver 1976, Moser 19761978), the psycholinguistic communication model (Kirchhoff 1976), and the probability prediction model (Chernov). 1979) and some partial processing models, such as the deep processing model (Lambert 1983), the text comprehension model (Dillinger 1989), and the general model of memory in simultaneous interpretation (Darò and Fabbro 1994).

\section{Gerver's processing model}

Gerver (1976) was one of the first to develop a model for the complete processing of simultaneous interpretation using the information processing method, but made it clear that his model was simply "the first approach to the model of processes involved". Gerver's technology model (1976) focused on two main aspects of the translation process.

Gerver's processing model performs a very complex cognitive task in simultaneous translation, where the interpreter has the ability to record, memorize well, and engage in sentence production and monitoring. Since the 1970s, various cognitive models of this complex task have been developed, including the information processing model (Gerver 1976, Moser 1976, 1978), the mental communication model (Kirchhoff 1976), and the low-level prediction model (Chernov 1979) and a processing model with some special processing (Lambert 1983), a complex text model (Dillinger 1989), and a general model of memory during simultaneous interpretation (darò and Fabbro 1994) are no exception.
In addition to endorsing the information processing process, Gerver (1976) reveals only the so-called "first approach to the process model" of his model. Gerver's processing model (1976) is based on two main aspects of the simultaneous interpretation process:

1. Permissible structural features The diversity of memory systems to strengthen the inputs and outputs allows different components of the task to be provided simultaneously;

2. The management process may also specify that monitoring and attention to different parts of the task be ensured, in particular by the interpreter.

According to Gerver, temporary storage plays an important role in simultaneous translation. Interpreters need to consolidate and store the incoming information when interpreting the other original message and the results of the analysis process steps should also be stored as soon as possible.

According to the Gerver process model, simultaneous interpretation includes input, decoding, and coding procedures, as well as output procedures. During login, the source text enters the temporary buffer storage location. According to Gerver, the coding and decoding process consists of two parts: "encoding and storing the source code" and "encoding and storing the target language". In the first part, translators mean "decoding the phonetic appearance of each segment of the source language and understanding it in terms of its basic structure and meaning in relation to the context" and the second part means decoding messages encoded in the target language. Translators can draw conclusions as soon as they understand the original language or check the translation in the original text before starting work, then stop if the translation matches the original text or if it does not match, or use another method to correct mistakes if time permits; they can try. This is the first comprehensive method of the simultaneous interpretation process [8]. 
Gile's Model of Movement in Simultaneous Translation

The above model clearly shows the complex operations of simultaneous translation, but has not been tested empirically. In contrast, the Gile motion model "was successfully applied to experimentally generate empirical data". This model is intended to be interpreted as an event such as "performance constraints and failures" and involves three actions in the simultaneous interpretation process, including listening and analyzing or understanding actions, and production actions (P-value) and memory excellent, etc.

Listening and analytical efforts include "all operations aimed at understanding, from analyzing the source language sound waves that reach the translator's ear until the words are identified and a final decision is made about the meaning of the sentence" 'includes.

Production activities include all outputoriented operations, "from the initial mental presentation of the delivered message to the planning of the speech and the implementation of the speech plan". In the Gile model, the source text should be based on the content, not on the four reasons. First, simultaneous translators may face difficulties arising from the syntactic structures of simultaneous interpretation due to grammatical differences between the two participating languages. Second, translators may lose the ability to behave naturally when speaking in another language at the same time. Third, literal translations lead to lexical interference between the two languages, resulting in simultaneous interpretation "grammatical errors, mispronunciations, false italics, original italics" (similar to bilingual, but non-such words). Fourth, careful observation of the source language can reduce the ability of translators to form hypotheses and understand the essence of the source text.

Memory action is the power expended to store data in short-term memory for later use. This can take up to a few seconds and runs continuously throughout the entire translation process. Short-term memory is required: (a) because of the time lag between the production of the source text and the production of the translation; c) with very high or very low density information, or with the characteristics of the speaker, such as stress; $d$ ) specific factors for each language, such as grammatical differences between languages.

According to Gile, problems with simultaneous translation, including "speech disorder in the target language," "errors and negligence," "disruption of its delivery," "linguistic infection, sound, and intonation," all of which are interpreted by translators. associated with efforts.

Gile's model of action focuses on the successes and shortcomings of simultaneous interpretation rather than on the simultaneous interpretation process [9].

\section{CONCLUSION}

In conclusion, because simultaneous interpretation is so complex, there can be a number of difficulties for translators in the practical process. The models created by the above scholars as a result of their research on the theory of simultaneous interpretation will help those working in the field of simultaneous translation, so that translators will have practical skills of simultaneous interpretation and will not face difficulties in simultaneous translation. After a detailed description of the process and knowledge models, it was determined that the simultaneous interpretation process is an action model of simultaneous interpretation as an ideal model for research.

\section{REFERENCES}

1. Xamidov X., Ismatullayeva N., Ergasheva S. Sinxron tarjima. - Toshkent: ToshDSHI, 2017. - 8-9 betlar. (Xamidov X., Ismatullayeva N., Ergasheva S. (2017) 
Simultaneous translation. - Tashkent. TSUOS. - pp. 8-9)

2. Jing Chen, Rongrui Yu, XiaoZhao. Interpreting Training in China: Practice and Research. Translation Studies in China. Singapore: Springer Nature Singapore Pte Ltd., 2019. - P. 91.

3. 现代汉语词典. - 北京 : 2015. - 第1306页.

4. Чернов Г.В. Основы синхронного перевода. - Москва: Высш. Шк., 1987. C.8. (Chernov G.V. (1987) Basics of simultaneous translation. - Moscow: Higher. - p. 8.)

5. 高峰. 同声传译过程中的话语输出研究. // 人文社会科学版 // - 吉林 : 吉林师范大学学 报. 2018年. 第4期.

6. Комиссаров В.Н. Теория перевода (лингвистические аспекты). - Москва: Высш. шк., 1990. - C. 98. (V.N. Komissarov. (1990) Translation theory (linguistic aspects). - Moscow. Higher. - p.. 98)

7. 邵张旻子. 同声传译局部认知负荷研究. 博 士论文. - 上海外国语大学, 2018.

8. Miao Wang. The Impact of Grammatical Differences on Mandarin Chinese-English Simultaneous Interpreting. Филол. фан. бўйиа фалс. док. ... дисс. - United Kingdom: University of Leicester, 2014.

9. 喵王. 语法差异对普通话汉英同传翻译的 影响. - . - : Филол. фан. бўйича фалс. док. ... Ancc.: 莱斯特, 2014年. 第25页.

10. Usmanova, Shoira Rustamovna; Ismatullayeva, Nargiza Rasuljanovna. Expression Of Lacunas In Comparative Study Of Kinship Terms In Chinese And Uzbek Languages. Solid State Technology, 63, 6, 4974-4985, 2020. 